Article

\title{
How Is Forest Landscape Restoration Being Implemented in Burkina Faso? Overview of Ongoing Initiatives
}

\author{
Barbara Vinceti $^{1, * \mathbb{D}}$, Michel Valette ${ }^{1,2}$, Ali Lardia Bougma ${ }^{3}$ and Arturo Turillazzi ${ }^{1}$ (D) \\ 1 Bioversity International, 00053 Rome, Italy; m.valette20@imperial.ac.uk (M.V.); \\ turillazzi.arturo@gmail.com (A.T.) \\ 2 Centre for Environmental Policy, Imperial College London, London SW7 2AZ, UK \\ 3 Department of Plant Biology and Physiology, University Joseph KI-ZERBO, Ouagadougou 03 BP 7021, \\ Burkina Faso; alilardia@yahoo.fr \\ * Correspondence: b.vinceti@cgiar.org; Tel.: +39-06-611-8412
}

Received: 21 September 2020; Accepted: 10 December 2020; Published: 14 December 2020

check for updates

\begin{abstract}
Land degradation affects a significant portion of the Earth's ice-free land area and several countries have embraced the challenge of restoring large parts of their degraded lands. Success in these efforts depends on various factors, including the amount of resources invested, the technical capacity available and the degree of involvement of stakeholders. Burkina Faso has committed to restoring 5 Mha of degraded land by 2030. We identified 39 forest landscape restoration initiatives (FLR) in this country and interviewed their managers to obtain an overview of critical aspects and constraints that could orient future efforts. Our results show a recent growth of FLR initiatives, as most of the projects examined started in the last few years; however, the scale of implementation seems incompatible with country-level targets. Funding is coming mainly from international cooperation and this may lead to risks in long-term continuity and sustainability of FLR. Furthermore, FLR projects are carried out by a multitude of agencies, with local NGOs and associations as the main players; this finding highlights the need to coordinate ongoing efforts and flag challenges in tracking progress. Tree planting is common to most FLR initiatives examined, with aspects of quality and quantity of planting material available becoming critical in ensuring success; this raises the need to ensure farmers are well-trained in its collection and handling. Finally, more homogeneous approaches in monitoring across FLR initiatives should be adopted.
\end{abstract}

Keywords: land degradation; forest landscape restoration; arid lands; tree planting

\section{Introduction}

Figures are greatly debated, but global estimates indicate that land degradation affects an area ranging from less than 10 to greater than 60 million square kilometers [1]. In order to combat environmental degradation, restoration initiatives have been put in place in different parts of the world, varying largely in their end goals, the approaches used, the resources available and the degree of participation of local communities [2,3]. Past experience has indicated that neither agricultural development nor conventional reforestation approaches have provided optimal solutions to simultaneously reach conservation targets, guarantee sustainable livelihoods and an adequate provision of ecosystem services. Thus, new concepts have been developed to address restoration objectives at the landscape level, using different combinations of approaches, ranging from managing natural forest regrowth to tree planting [2], maximizing livelihood improvements in addition to reaching biodiversity conservation goals. Drawing from these considerations, the concept of forest landscape restoration (FLR) has 
been gradually reaching visibility. The original definition of FLR describes it as "a planned process that aims to regain ecological integrity and enhance human well-being in deforested or degraded landscapes" [3,4]. It is different from site-level restoration because it targets ecological processes that operate at a larger landscape scale $[5,6]$, and it aims at optimizing the flow of ecosystem services and goods from trees in the landscape. The FLR framework is meant to be flexible enough to encompass different ecosystem restoration approaches applied in different parts of the landscape, based on site-specificities. These approaches, as identified by the Society of Ecological Restoration and other authors $[7,8]$ span from ecological restoration (aiming at recovering most characteristics of the original ecosystem), to rehabilitation (intervention that focuses on functional recovery, involving also native species) and reclamation (intervention that turns disturbed land into a desired state, reconstituting only some functions). A landscape-level management approach integrating trees, forests and forestry with other land uses has been considered likely to produce sustainable outcomes [9], especially in dryland landscapes, where forests and trees are part of a mosaic of land uses in which they play an essential role in sustaining livelihoods.

In Africa, 30 countries have committed to embracing the challenge of restoring significant portions of their land by participating in the African Forest Landscape Restoration Initiative (AFR100; https: //afr100.org). This is a regional country-led effort supported by the African Union that contributes to the achievement of domestic restoration goals and sustainable development commitments. AFR100 adheres to international targets and agreements, such as the Aichi Biodiversity Target 15 [10], the Bonn Challenge [11], and the Sustainable Development Goal 15 [12], with an overall objective to restore 100 million hectares of degraded land in Africa by 2030.

Burkina Faso is among the countries that joined AFR100 with a commitment to restore 5 Mha of degraded land by 2030 (http://afr100.org/content/burkina-faso). In this country, droughts and expansion of cultivated areas have caused a considerable loss of natural woody vegetation and triggered degradation processes, which affect ca. 470,000 ha/year, equivalent to ca. 19\% of the country, based on estimates by the Ministry of Environment, Green Economy and Climate Change of Burkina Faso [13]. Environmental degradation can be found across all ecoregions in Burkina Faso (Sahelian and Sudanian), and the country lost 22\% of its forest cover and 18\% of other woodlands between 1990 and 2015, according to statistics by the Food and Agriculture Organization FAO [14]. The remaining forest cover has also been affected by fragmentation [15].

A growing number of FLR projects have been set in place by different agents in Burkina Faso, as a result of the restoration pledges put forward by the government. However, an aggregated analysis of the various ongoing activities is missing. The purpose of this study is to take stock of existing experience in implementing solutions to slow down degradation and foster restoration in forest landscapes in Burkina Faso. We analyzed initiatives that aimed at increasing tree cover within mosaic landscapes with different land uses, with trees occurring at varying densities compatible with other uses of the land (e.g., agroforestry systems). We assessed whether ongoing initiatives are implemented at a pace that will enable country-level restoration targets to be reached. We examined the sustainability of the efforts set in place based on the type of funding and agents involved. We looked at which approaches are used for FLR, at the technical barriers and solutions found, particularly with regard to tree establishment, and examined what lessons learnt are emerging, with the ultimate objective to orient future efforts.

\section{Materials and Methods}

To carry out this study we produced an inventory of FLR initiatives ongoing in Burkina Faso. The initiatives targeted were, to different extents, aiming at bringing back a tree cover in the landscape, as well as pursuing a variety of objectives, including the restoration of the productive functions of the land to sustain local livelihoods. A description of the initiatives targeted for this study was provided to the resource people contacted. The Forest Department in charge of coordinating FLR efforts in connection with the Great Green Wall Initiative secretariat, hosted at the Ministry of Environment, 
Green Economy and Climate Change, provided a list of organizations in charge of FLR and their areas of intervention. Furthermore, the National Tree Seed Center, in charge of supplying planting material to a large number of restoration initiatives, shared additional information on existing FLR projects and on implementing organizations active in restoration in different regions of Burkina Faso. The list of FLR initiatives provided by local institutional contacts was supplemented by a search on the internet of additional ongoing relevant projects, to be sure that our inventory would be as comprehensive as possible.

After assembling the list of FLR initiatives, a preliminary contact was established with the responsible institutions and organizations identified. This step helped to filter out organizations that were no longer active and, at the same time, to broaden the list of target organizations through a snowball sampling approach, by which managers of restoration projects indicated additional subjects for this study based on their network of contacts. The objective was to ensure the list would be as complete as possible and inclusive of the most significant ongoing FLR initiatives. After excluding those no longer active, a total of 39 initiatives, some of which were implemented in multiple sites, were retained (see details in Supplementary Materials, Table S1). Their geographic distribution covered five different regions of the country (Figure 1), located in the Sahelian and the northern part of the Sudanian ecoregions, which present distinct features. The Sahelian ecoregion is characterized by annual rainfall ranging between 150 and $600 \mathrm{~mm}$, mainly between June and September. The vegetation is mostly characterized by wooded grasslands, with herbaceous species and trees (mainly acacias) scattered across the landscape. Extensive animal husbandry is the main activity, practiced by semi-nomadic groups, but cereal farming is becoming increasingly common. The Sudanian ecoregion is characterized by annual rainfall ranging between 600 and $1200 \mathrm{~mm}$, concentrated mainly from May to October. The prevalent mix of land uses includes traditional agroforestry systems, where useful tree species are spared during clearing (parklands), and other woodlands and pastures. The main cultivated crops are cereal and cash crops. Extensive animal husbandry is also largely practiced, primarily by semi-nomadic groups.

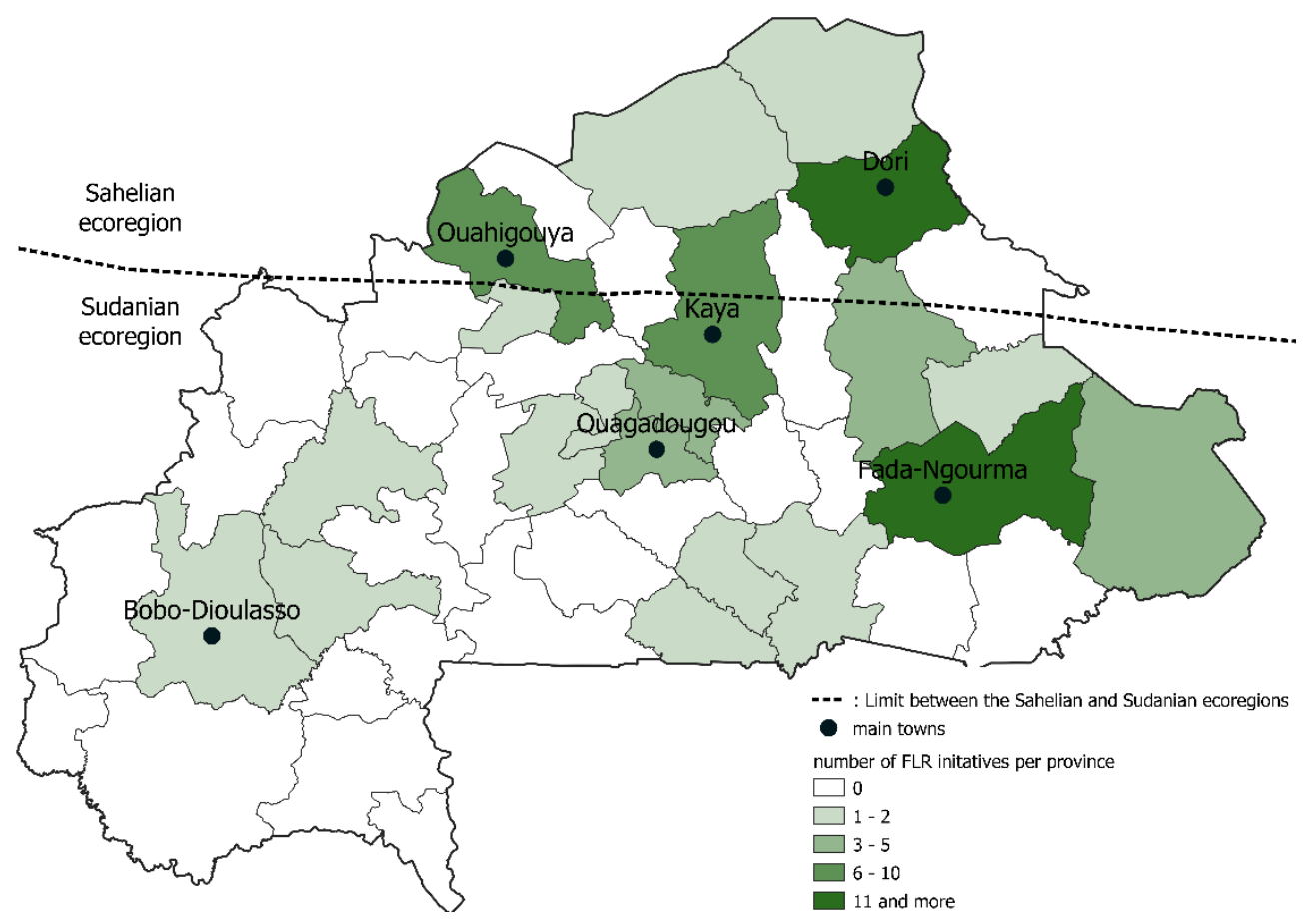

Figure 1. Location of the forest landscape restoration (FLR) initiatives analyzed. Provinces in darker green had a higher number of initiatives targeted by this study. 
A semi-structured interview, with both closed and open questions, was conducted involving a project/program manager or another resource person representing each initiative identified. Field trips were organized between March and April 2019 to initiatives' facilities and offices, located in settlements in rural areas and in the capital city (Ouagadougou), to carry out interviews in person with their staff. The survey questions were sent in advance to each organization to ensure that relevant information could be gathered and prepared and a staff member with the right experience and knowledge could be identified for interview. Interviews generated both quantitative and qualitative information and were focused on documenting the following aspects (see details in Supplementary Materials, Full Survey): main goals of each restoration initiative selected, sites of interventions, years of activity, funding mechanisms, degree of involvement of different stakeholders, technical aspects in the implementation of FLR activities, seed sources used for tree planting and the main constraints faced in achieving the initiatives' objectives. The language used was French. Responses were coded and categorized for the analyses. The survey was developed following the structure of an earlier survey on forest restoration initiatives, conducted in Colombia by Murcia and Guariguata [16], to enable future comparisons across multiple countries. Although the survey developed by Murcia and Guariguata was more focused on ecological restoration, the overall structure and the options presented for closed answers were suitable to also capture the main traits of FLR initiatives (see details in Supplementary Materials, Table S2). Of the different aspects covered in the survey, we decided to present here only the results that looked the most robust, supported by clear answers from all respondents, without gaps or incomplete responses. In some cases, we excluded from our presentation of results those survey sections that seemed more difficult to treat, in particular those related to an assessment of the costs of FLR initiatives, because respondents provided aggregated figures that covered very different types of interventions, limiting the possibility of comparing values across projects.

With regard to the type of land tenure in FLR projects, we identified categories based on whether the land undergoing restoration was public or managed privately (i.e., at the household level), and whether it had a protection or a production regime, following the classification used by Murcia and Guariguata [16] (see details in Supplementary Materials, Full Survey).

\section{Results}

\subsection{Characteristics of FLR Initiatives Implemented in Burkina Faso}

The spatial distribution of FLR initiatives surveyed mirrors the patterns of land degradation in Burkina Faso, as revealed by national assessments of the Ministry of Environment, Green Economy and Climate Change [17], with restoration efforts concentrating in the Sahelian ecoregion and in the northern part of the Sudanian ecoregion, both severely affected by land degradation processes (Figure 1).

The survey revealed that just 3 out of 39 initiatives have been in place since the late 1980s-early 1990s (see Supplementary Materials, Table S1), while the majority of the FLR initiatives sampled (59\%) started their activities in 2016 or later. It is interesting to note that one of the longest existing efforts started as an initiative of an individual, Yacouba Sawadogo, an emblematic smallholder who started 30 years ago rehabilitating traditional cultivation practices to conserve soil fertility and manage water. His land now works as a demonstration plot and provides an example of sustainable agricultural practices and nursery management. All other long-lasting efforts recorded in this study have been managed by local NGOs or associations.

The most common source of funding was multilateral cooperation (primarily through UN programs and regional initiatives) (Figure 2). In $54 \%$ of the cases, funding came from multiple sources. In total, the 39 initiatives examined had a target of restoring 78,756 hectares, as of 2020. Most individual targets ranged between 100 and 1,000 ha; target areas of $<100$ ha represented a minority (Figure 2b). 

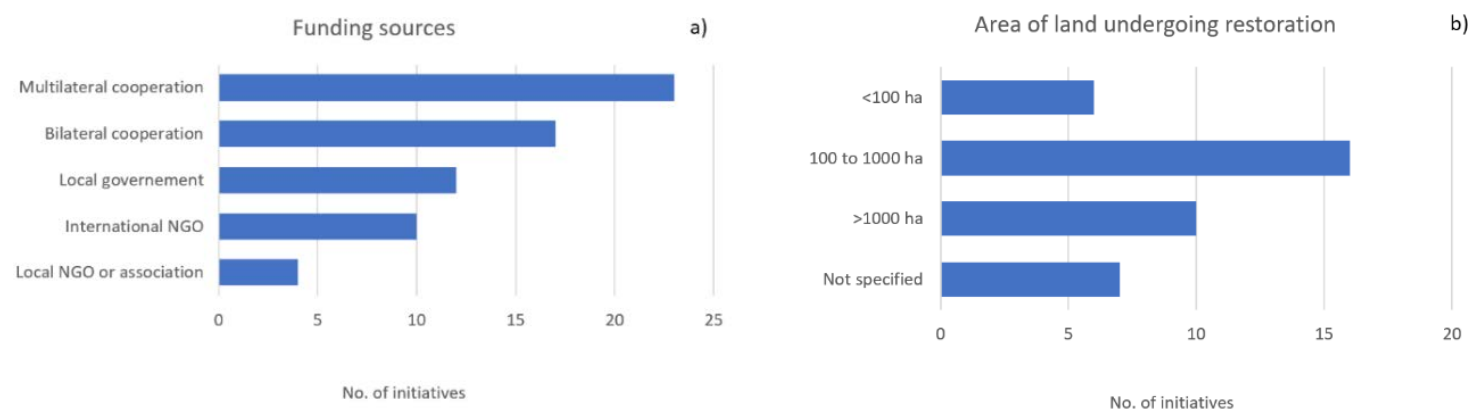

b)

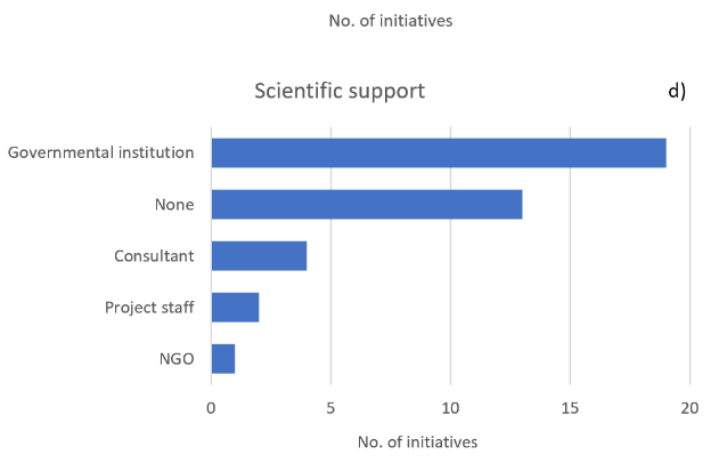

Figure 2. Number of initiatives based on groupings related to (a) type of funding sources (multiple sources of funding were reported, sum does not add up to 39); (b) area of land undergoing restoration by individual initiatives at the time that this study was conducted; (c) type of implementing agency; (d) providers of scientific support. NGO = non-governmental organization.

We identified four main types of implementing agencies: local NGOs or associations, local government (national or subnational), international institutions (including international or intergovernmental organizations established by treaties among sovereign states, e.g., UN organizations) and international NGOs (non-governmental organizations with an international scope). In $49 \%$ of the cases, FLR initiatives were implemented by local NGOs and associations, followed by international organizations (26\% of cases) and, in a smaller number of cases, by the local government and international NGOs (Figure 2c). Scientific support was provided by governmental institutions in $45 \%$ of the cases examined; however, $33 \%$ of the initiatives did not have any scientific backup (Figure $2 \mathrm{~d}$ ). Larger organizations (international or intergovernmental organizations) tended to subcontract local associations, or groups representing local communities, in the implementation of restoration activities.

In $46 \%$ of the cases described, intervention sites were located on privately managed land, used for agro-sylvo-pastoral activities; another $41 \%$ of the initiatives focused on public land under a protection regime (e.g., national park, communal forest) and 38\% of the initiatives were implemented on public land without a formal protection regime (Figure 3). Most FLR initiatives (61\%) involved just one type of land and a minority of FLR initiatives (13\%) targeted a composite mix of more than two land types (defined based on land tenure and use). The three most commonly cited goals of FLR were the recovery of ecological functionality, an increased resilience of local communities to climate change and the promotion of agro-sylvo-pastoral productivity (Figure 4). 


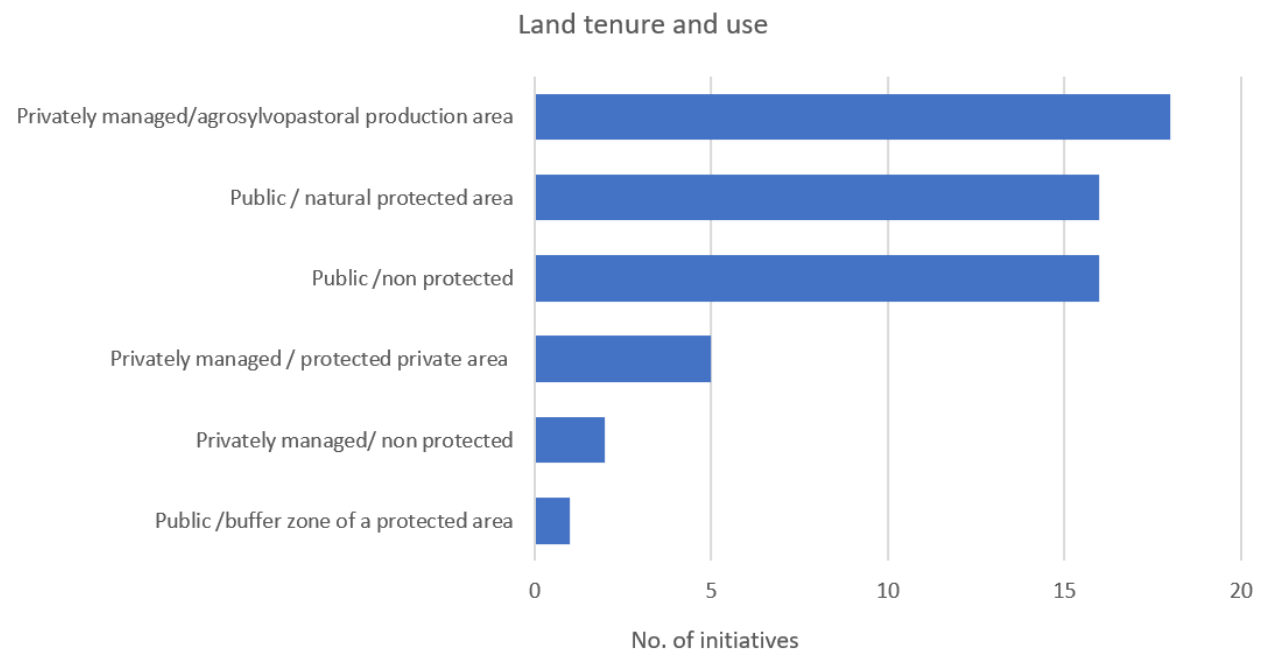

Figure 3. Type of land used in the FLR initiatives examined. The survey allowed multiple responses.

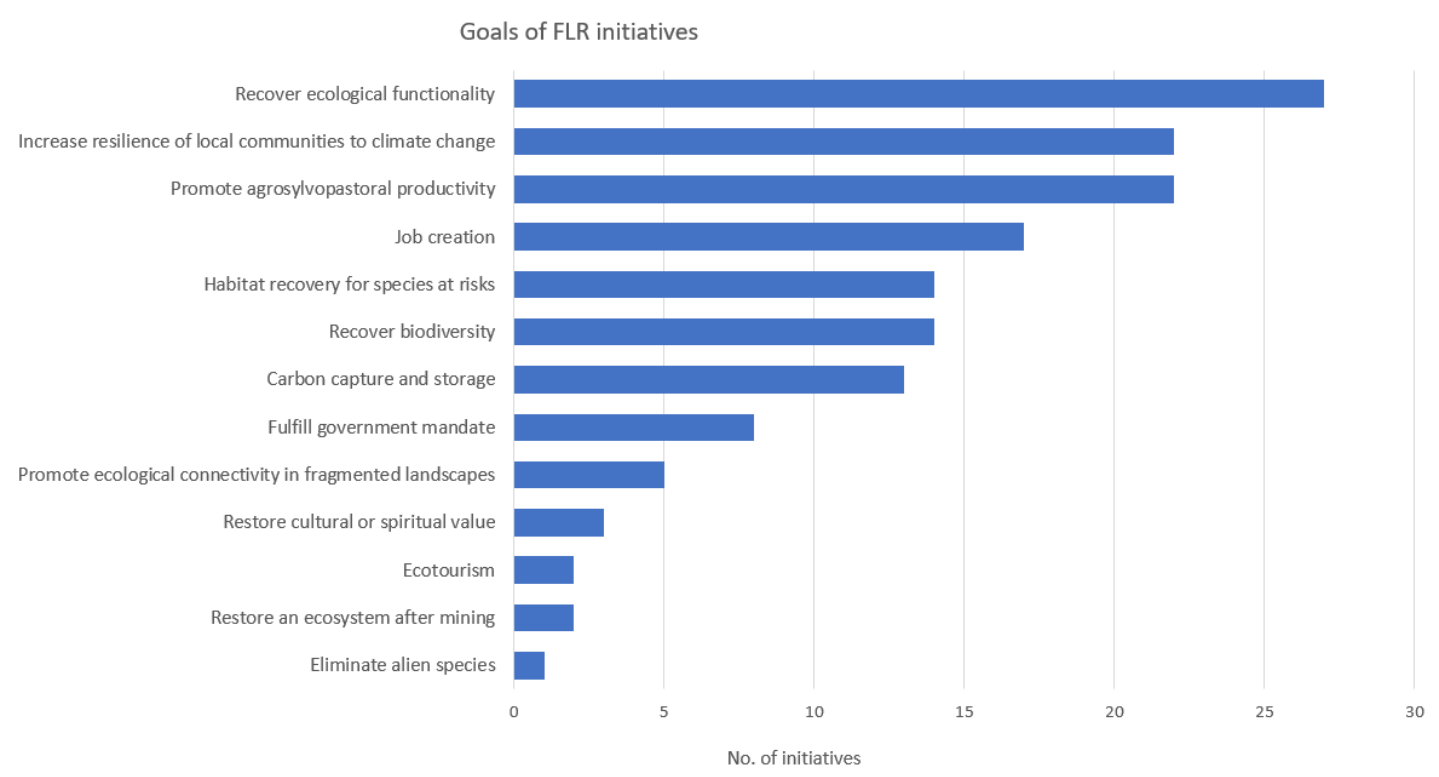

Figure 4. Main goals reported by each FLR initiative. The survey allowed multiple responses.

\subsection{Different FLR Approaches Adopted}

Most FLR initiatives targeted (92\%) were centered on planting trees (Figure 5); in 49\% of cases trees were not planted alone, but in association with shrubs and herbs. The tree species most commonly planted were largely indigenous ( $62 \%$ of the species cited), providing valuable non-timber forest products (such as fruit, seeds, leaves and bark). They included also forage species and thorny species useful for fencing (see Table S3 in Supplementary Materials for a list of tree species planted). In $61 \%$ of cases, selection criteria for native trees were based on preferred species traits matching local needs (e.g., production of an abundant litter to restore fertility), explicit demand from project beneficiaries $(15 \%)$, availability of the seeds $(13 \%)$, and easy propagation $(8 \%)$.

Tree planting was combined with use of natural regeneration in $61 \%$ of the projects. Soil and land management practices were also adopted in $61 \%$ of the initiatives. Soil and land management practices are often essential preliminary operations before planting in drylands, as they contribute to restoring fertility, reducing erosion and favoring water capture during the rainy season. They consist mainly in the creation of stonewalls, half-moons, Vallerani trenches [18], and zaï pits (see Table S2 in Supplementary Materials for a detailed description of soil and land management practices). 
FLR approaches adopted

Planting of trees (alone or in combination with shrubs and herbs)

$$
\begin{array}{r}
\text { Natural regeneration } \\
\text { Soil/land management/ fertilization } \\
\text { Restoration of the fire regime } \\
\text { Planting of species with specific ecological attributes } \\
\text { Monospecific planting of exotic trees } \\
\text { Monospecific planting of grass } \\
\text { Fauna restoration }
\end{array}
$$

Control of pollutants

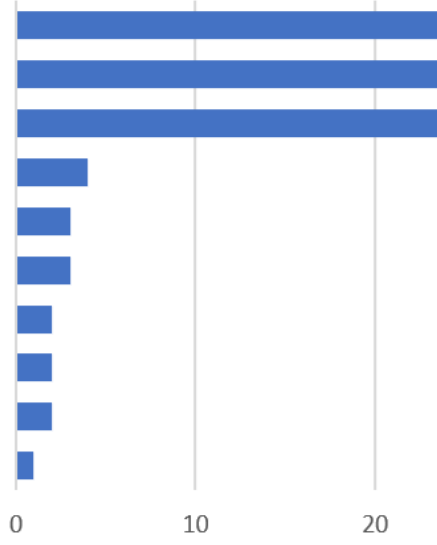

No. of initiatives

Figure 5. Types of approaches used to implement FLR. The survey allowed multiple responses per each FLR initiative targeted (see Supplementary Table S2 for more details on different technical solutions used in restoration).

In $56 \%$ of the FLR initiatives, the supply of planting material (seed/seedlings) was provided by an institutional source, the National Tree Seed Center of Burkina Faso (CNSF), either from the central office in Ouagadougou or from its regional facilities (Figure 6). In $28 \%$ of the cases, the main source of planting material was self-collection carried out locally, either by staff of FLR initiatives or by local smallholders involved in the project. About half of the FLR initiatives (49\%) had established their own nurseries to meet the demand for forest reproductive material. Only for about a third of the initiatives $(31 \%)$, was it possible to obtain figures about annual seedling production, which in $13 \%$ of the cases was above 50,000 seedlings/year. Limited access to water was the most frequently reported constraint, indicated by $56 \%$ of the initiatives. Among other constraining factors, lack of funding and damage produced by animals trampling on seedlings in restoration sites (Figure 7) ranked in second and third position, respectively. Issues related to the involvement of local communities were reported by only three FLR initiatives.

In $78 \%$ of the initiatives, monitoring of targets' achievements was carried out through approaches that varied largely, from the implementation of field assessments based on protocols defined within each initiative ( $39 \%$ of cases), to the hiring of external consultants (18\% of the cases), the use of satellite images (13\% of cases) or the involvement of staff from local or central institutions, charged with the task of reviewing progress.
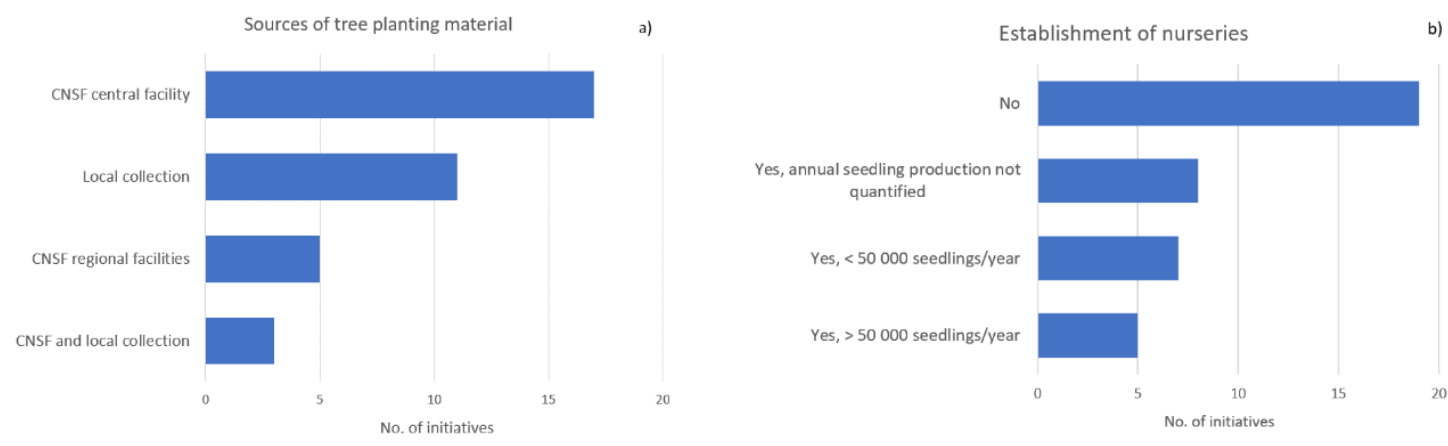

Figure 6. Supply of tree planting material for FLR initiatives: (a) main sources reported (one response per each FLR initiative). CNSF: National Tree Seed Center of Burkina Faso; (b) establishment of nurseries. 


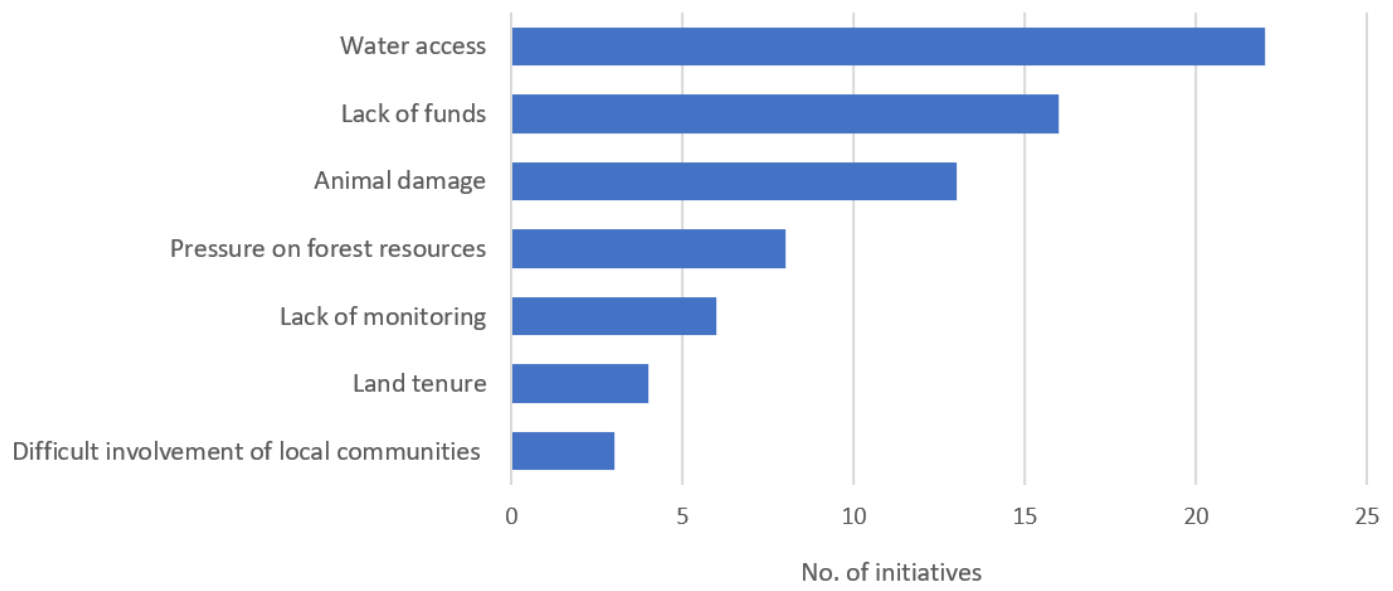

Figure 7. Constraints affecting the implementation of FLR initiatives. The survey allowed for multiple responses per each FLR initiative.

In $85 \%$ of the initiatives, the direct beneficiaries were involved in FLR, but mainly provided labor for restoration activities, generally without remuneration. With regard to gender aspects, in $33 \%$ of the initiatives, women were explicitly included among the beneficiaries of restoration, although this generally entailed an engagement in temporary task assignments. In $15 \%$ of cases, women could participate in decision-making by becoming members of a management committee. In only three cases it was reported that women could access land to implement restoration activities; however, not individually, but organized in associations. Training of local beneficiaries was reported in $98 \%$ of the initiatives. Capacity building was largely focused on practical aspects related to tree planting and soil management and was carried out by extension services (35\% of cases), resource persons or consultants $(23 \%)$, research institutions (5\%), staff of the organization in charge of project implementation (5\%) and forestry officers $(5 \%)$.

\section{Discussion}

\subsection{Types of FLR Initiatives in Place in Burkina Faso}

Most FLR initiatives covered in this analysis are less than five years old and this seems to reflect the recent growing efforts to halt land degradation in Burkina Faso and the commitment to allocate resources to recuperate those lands that have lost any productive function. In our selection of initiatives, we excluded those no longer actively managed through a program or a project, which injects human and financial resources to support restoration efforts, as it would have been hard to identify a suitable local resource person able to provide a detailed overview. However, despite the fact that our figures include only active programs and projects, the country seems far from reaching its restoration commitments. The 39 forest landscape restoration initiatives examined contribute collectively less than $2 \%$ to the overall country-level target to restore 5 million hectares of land by 2030, based on the pledges of Burkina Faso within the frame of AFR100, corresponding to 415,000 ha/year. This points to the need to increase the scale of forest restoration efforts in order to meet the recently defined country-level targets. However, quality of the efforts set in place is a key aspect to take into account; past experience has shown low survival rate in large scale tree plantations, while individual or small-scale collective efforts, such as exclosures or "Sahelian bocage" have been more successful, although more costly [19]. The "Sahelian bocage" is an approach piloted in the 1990s in one site in Burkina Faso and has now been adopted in other experimental farms; it consists of a rural landscape with individually owned plots and common grounds all surrounded by live fences. The meadows and/or fields are managed through an informal co-ownership of the landowners, who form an association of beneficiaries. Within the 
perimeter of the bocage, fields are no longer exposed to the pressures of overgrazing; a system of earth dykes, ponds and hedges prevents soil erosion, and trees and bushes are integrated into crop cultivation [20]. However, the initial costs are significant (500 euro/ha); in addition, a collaborative attitude among farmers must be in place. Similarly, the existing experience of establishing fenced plots indicates that the highest capital cost relates to the initial purchasing of fencing material [21].

Based on our sample of FLR initiatives, the most common sources of funding were bilateral and multilateral cooperation (primarily through UN programs and regional initiatives); this finding directs attention to the fact that the significant and growing investment in FLR in Burkina Faso is largely sustained by external funding sources. FLR is a long-term process, so it should be sustained by long-term funding. Financial resources coming from sources external to the country may not provide sufficient continuity to adequately sustain efforts in place. This reminds us that forest landscape restoration needs to become an economically attractive opportunity [22], and the different values of forests should be recognized; for example, through mechanisms such as payments for environmental services (PES), although their implementation may be very complex and dependent on the local context [23]. In addition, FLR should be sustained by public funding coming from different programs, not only focused on the environment but also, for example, focused on poverty reduction. About $80 \%$ of the population in Burkina Faso is involved in agricultural activities and rural communities rely strongly on dry forests and woodlands for their livelihoods; in particular, generating income from non-timber forest products, diversifying their diet and accessing medicinal products [24,25]. In addition to these uses, forests also play the role of a safety net in case of low agricultural yields [26].

In the actual implementation of restoration in Burkina Faso, non-state actors such as NGOs and associations have a major role in a large part of the restoration efforts in place. This poses questions regarding the scientific and technical support that small-scale organizations can count on in their efforts. From our survey, scientific support was mainly provided by governmental institutions, but a third of the initiatives did not have any kind of scientific assistance. In addition, the multitude of operations and lack of a standardized system for monitoring progress across existing initiatives pose challenges in scaling up FLR efforts, making it harder to coordinate interventions, take stock of positive experiences and understand what recurrent bottlenecks should be addressed to increase the success rate of FLR projects $[13,27]$. In order to achieve these objectives, coordinating platforms and networks play an essential role.

With regard to coordination and harmonization of approaches, Burkina Faso is part of a large regional program, the Great Green Wall initiative (GGWI), aiming to build resilient landscapes in 21 African countries by restoring degraded arid lands. The initiative focuses on the restoration of multiple ecosystem services and poverty alleviation to avoid further degradation of the forest [28]. It has offered a platform for the co-operation of stakeholders such as the local communities, governmental institutions, NGOs and scientists, thus creating an opportunity to include many perspectives for guiding strategic choices and to benefit from a synergy between research and implementation [29]. The original idea was proposed in the 1980s and was later embraced by the Africa Union and revived with the signing of all 11 Sahelian countries in June 2010. However, the initiative has encountered some criticism at local and international levels. Detractors argue that the GGWI has marginalized local people in decision-making processes, and that the lack of adhesion of local communities and regional decision makers will compromise the long-term sustainability of the program [30]. Furthermore, it has been observed that the emphasis on converting agricultural land to tree monocultures may put pressure on the water system and may also lead to a loss of traditional livelihoods [31].

\subsection{FLR Approaches Adopted}

The sample of initiatives targeted in this survey had a fair geographic spread and covered different FLR approaches. Both the restoration of ecological functionality and production were targeted in the majority of cases. Approaches tended to vary based on the vocation of the land to be restored (e.g., forest, agricultural or pastoral land); in our sample of initiatives examined, FLR often translated 
into tree planting, which is a necessary option in the case of excessive harvesting pressure, or lack of natural regeneration for some species [32,33].

Tree planting was carried out alone or with preparatory plant species, such as herbs and shrubs that contribute to restoring the soil, preparing the ground for, or accompanying, tree planting. Evidence from pilot sites in Mali, Burkina Faso and Niger has revealed that combining the planting of slow-growing indigenous trees or shrubs with fast-growing native edible herbaceous and fodder species for livestock leads to very successful outcomes $[34,35]$. Herbaceous plants are critical for supporting agro-pastoral systems but also play a role in soil protection, creating soil-retaining vegetative barriers, contributing to the fixation of dunes and litter accumulation [9]. Research has shown that nurse shrubs positively modify the establishment conditions for tree seedlings through a canopy effect, which influences the microclimate by reducing air and soil temperatures, radiation and vapor pressure deficit. In addition, nurse shrubs have been found to modify soil properties by trapping windblown particles and generating organic litter, increasing potassium concentrations in the soil and thereby improving water use efficiency in plants $[36,37]$. Finally, by spanning spatially disconnected areas of soil moisture with their roots, shrubs can favor a redistribution of moisture within the soil profile, producing positive effects for the associated vegetation. Hydraulic redistribution has been found in native woody shrub species in the Sahel, such as Guiera senegalensis [38] and Piliostigma reticulatum [39,40].

With regard to tree species chosen for planting, from other studies it emerged that smallholders in Burkina Faso prefer planting exotic tree species with important market value [41-43], so exotic trees appear to be dominant both in small-scale commercial tree plantations and FLR projects $[17,19]$. However, the data collected in this survey of FLR initiatives indicate a growing interest of restoration practitioners in using native tree species, which could have an increasing role to play in FLR, given that they are culturally and ecologically adapted to local conditions and considering the available growing knowledge of the characteristics and potential of native species [35,44]. In this way, FLR projects could also fulfil conservation objectives, ensuring a recovery of tree species and tree populations that are locally disappearing $[45,46]$.

Natural regeneration was the second most common approach reported in the sample of FLR initiatives targeted. Natural regeneration approaches are a cost-efficient solution to scale-up restoration efforts and allow the regeneration of a diversity of native species $[47,48]$. Farmer-managed natural regeneration has been widely adopted by smallholders in Niger [48] and other West African countries because of its low cost. It has led to substantial livelihood benefits, increased social capital and re-greening of large patches of land [49-52]. Exclosures are successful in restoring soil properties and fostering a spontaneous regrowth of a diverse vegetal community $[53,54]$. However, the implementation of individual fenced plots can be costly [55], as experienced in the establishment of small-scale fenced plots in Burkina Faso [21]. The installation of communal exclosures has been largely implemented in the highlands of Ethiopia, but the limited economic outcomes and lack of transparency for benefits sharing has partly hampered the long-term success and up-scaling potential of this approach [56,57].

The adoption of soil and land management practices was reported in a large number of FLR initiatives in our study, ranking in third position. These practices are a fundamental part of restoration efforts in the Sahelian ecoregion, especially in agricultural and pastoral lands (see Table S2 in Supplementary Materials). Sustainable land management practices have been implemented in large parts of the country to improve the agricultural yield and combat land degradation, but also to favor tree regeneration [58-60]. In arid environments, the establishment of a tree cover in highly degraded sites requires soil management measures to limit soil erosion, recover fertility and slow down runoff through water management techniques, such as the creation of stone bunds and the preparation of half-moons or zaï pits (see details on soil management practices in Supplementary Materials, Table S2) [61,62].

With regard to tree planting material for artificial regeneration, about three quarters of the FLR initiatives analyzed had obtained at least part of their planting material from an institutional source, the National Tree Seed Center of Burkina Faso (CNSF). CNSF collects seeds for 166 ligneous species 
and 6 herbaceous species (overall, ca. $70 \%$ of these are indigenous) in six different zones to match the climatic conditions of different planting sites. It applies standard procedure for seed treatment and testing of germination rate before sale. This allowed FLR project managers to access a wide diversity of tree species for their tree plantations. However, the second most commonly cited approach to seed sourcing was self-collection, carried out locally (either by staff of FLR initiatives or by local smallholders involved in the project). Appropriate training of smallholders in seed collection and handling seems to be a critical investment to scale up FLR in Burkina Faso, and would also help to avoid future losses associated with the potential failures in tree establishment. Quality of planting material and not just quantity should be an aspect to focus on with greater attention, as survival rates and growing performance of planted trees depend on it. The common survival rate in ongoing national reforestation campaigns has been less than $25 \%$; some of the reasons are extreme pressures posed by grazing, bush fires and termites, but also the inadequate choice of planting material and planting period have been identified among the factors that compromise success [17].

Quality is critical in cases where tree planting is entirely locally driven and based on a seed supply from informal sources, both for trees and crops $[41,63]$. Experiences of nursery capacity reinforcement in agroforestry showed that repeated capacity enhancement for seedling production is often needed, but this is challenging when funds are available for a limited period of time and seedling production takes place for only one generation of seedlings [64-66]. Continuous training and interventions to raise the demand (e.g., buy-back arrangements, promotion of tree planting by smallholders) can provide the opportunity to transform nurseries into sustainable business ventures and increase the availability of seeds to smallholders in the long-term $[67,68]$. Ensuring quality is not critical only in seed collection and testing but also in nursery management practices [69,70]. Quantity of planting material may also be a crucial aspect in Burkina Faso. The majority of the FLR initiatives surveyed established nurseries to produce tree seedlings. However, even considering that upscaling of FLR may be largely grounded on natural regeneration and farmers' managed regeneration, the current amount of seedlings produced seems largely insufficient to meet the demand.

Lack of water availability was found to be a major constraint for FLR in Burkina Faso as in most arid environments. However, almost all initiatives that reported critical limitations in water availability had found ways to mitigate this problem, most often using half-moons, zaï, stone walls or other water conservation practices, which were cheaper than drilling a well. Another commonly reported solution was the selection of restoration sites located in proximity of wells established for other purposes (e.g., for growing vegetables). The second most common constraint reported was lack of funding, followed by animal grazing. Practices to alleviate the effects of overgrazing and animal trampling, such as farmer-assisted natural regeneration (where farmers manage the regeneration of non-planted trees through pruning, protection of seedlings or other techniques) and exclosures were all reported as common practices.

A successful implementation of restoration projects generally requires collaboration of diverse actors (e.g., local institutions, policy makers, scientific organizations and implementers) and the strong involvement and support of local communities living in proximity to sites of intervention. Evidence shows that their deeper engagement in a planning phase would increase chances of success in interventions [71,72]. In the sample of FLR initiatives investigated, lack of involvement of local communities was reported as a constraining factor only in three initiatives out of 39; two of these were managed by international NGOs so the relationship with local communities might have been less close than in projects managed by local NGOs. Capacity building was a common activity in the majority of the FLR initiatives assessed, which indicated a widespread intent to raise the skills of local communities. However, our findings indicate also that women were excluded from most steps of FLR projects, and local communities were included as beneficiaries and labor force in FLR projects, but they had limited decision-making power over critical aspects of project design, so "participatory exclusion" was perpetuated $[72,73]$. 
Based on our findings, monitoring of progress has not followed a standard set of indicators or a common approach across the various FLR initiatives. Some projects used satellite images for monitoring, which enabled tracking of changes in vegetation cover. However, ground monitoring is also essential to understanding the success of FLR projects. Research findings have revealed that while analyses of satellite images have shown a re-greening of the Sahel since the 1990s, field observations have indicated that the observed trend in many instances could be attributed to the growth of shrubs; overall, the vegetation had lost diversity and a change in species frequencies was detected, with a shift towards more drought-resistant exotic species [74,75]. In addition, qualitative targets should be considered in monitoring. Most FLR initiatives have been using simple indicators to measure performance (e.g., counting surviving seedlings), while other critical qualitative indicators could be adopted, for example examining which strategies have been used for sourcing planting material [76], or analyzing changes in social dimensions, for example the number and type of social groups benefiting from restoration, the degree of improvement in tenure rights and community engagement in FLR [77]), up to longer-term factors, such as the overall improvement of socio-economic conditions of rural communities [78].

\section{Conclusions}

Our overview shows that most FLR initiatives in place in Burkina Faso are quite recent, reflecting a growing effort to halt environmental degradation and restore ecological functionality and production in degraded lands. However, the scale of implementation of FLR does not yet seem aligned with country-level commitments. Furthermore, funding for FLR comes mainly from international cooperation and this may pose some risks in terms of continuity of FLR efforts in the long run. We observed that FLR initiatives are carried out by a multitude of organizations and agencies, and the main players are local NGOs and associations. This poses a need to coordinate interventions and track progress across several initiatives that pursue multiple objectives. Tree planting is common to most FLR initiatives examined and aspects of quality and quantity of planting material available are critical for the success of tree establishment, underlying the need to ensure that best guidelines for procurement of tree planting material are widely disseminated and farmers adequately trained, especially considering the important role of self-collection recorded in half of the FLR initiatives analyzed. Finally, the diversity of approaches used to track progress calls for the adoption of more homogeneous monitoring standards, in order to generate aggregate figures and assess developments at country level.

Supplementary Materials: The following are available online at http://www.mdpi.com/2071-1050/12/24/10430/s1, Table S1: List of initiatives targeted in this study (39 in total), Table S2: Main forest and land restoration practices adopted in the context addressed by this study, Table S3: List of tree species used in the different FLR initiatives documented in this study, Full Survey.

Author Contributions: Conceptualization, B.V.; methodology, B.V.; formal analysis, M.V.; investigation, A.L.B.; data curation, M.V. and A.T.; writing—original draft preparation, B.V. and M.V.; writing—review and editing, B.V. and M.V.; supervision, B.V.; project administration, B.V.; funding acquisition, B.V. All authors have read and agreed to the published version of the manuscript.

Funding: This work was funded by the Austrian Development Agency within the framework of the project "Nutrition-sensitive forest restoration to enhance the capacity of rural communities in Burkina Faso to adapt to change" (Grant A1237; 2015/02) and by the CGIAR Research Programs on Forests, Trees and Agroforestry (FTA).

Conflicts of Interest: The authors declare no conflict of interest.

\section{References}

1. Gibbs, H.K.; Salmon, J.M. Mapping the world's degraded lands. Appl. Geogr. 2015, 57, 12-21. [CrossRef]

2. Lamb, D.; Erskine, P.D.; Parrotta, J.A. Restoration of degraded tropical forest landscapes. Science 2005, 310, 1628-1632. [CrossRef] [PubMed]

3. IUCN; WWF. Forests Reborn: A workshop on forest restoration. In Proceedings of the WWF/IUCN International Workshop on Forest Restoration, Segovia, Spain, 3-5 July 2000. 
4. Mansourian, S.; Dudley, N.; Vallauri, D. Forest Landscape Restoration: Progress in the Last Decade and Remaining Challenges. Ecol. Restor. 2017, 35, 281-288. [CrossRef]

5. Lamb, D.; Stanturf, J.; Madsen, P. What Is Forest Landscape Restoration? In Forest Landscape Restoration; Stanturf, J., Lamb, D., Madsen, P., Eds.; Springer: Dordrecht, The Netherlands, 2012; Volume 15, pp. 3-23. ISBN 978-94-007-5325-9.

6. Brancalion, P.H.S.; Chazdon, R.L. Beyond hectares: Four principles to guide reforestation in the context of tropical forest and landscape restoration: Forest and landscape rest oration principles. Restor. Ecol. 2017, 25, 491-496. [CrossRef]

7. McDonald, T.; Gann, G.D.; Jonson, J.; Dixon, K.W. International Standards for the Practice of Ecological Restoration-Including Principles and Key Concepts; Society for Ecological Restoration: Washington, DC, USA, 2016; p. 48.

8. Chazdon, R.L.; Brancalion, P.H.S.; Laestadius, L.; Bennett-Curry, A.; Buckingham, K.; Kumar, C.; Moll-Rocek, J.; Vieira, I.C.G.; Wilson, S.J. When is a forest a forest? Forest concepts and definitions in the era of forest and landscape restoration. Ambio 2016, 45, 538-550. [CrossRef] [PubMed]

9. Food and Agriculture Organization. Global Guidelines for the Restoration of Degraded Forests and Landscapes in Drylands: Building Resilience and Benefiting Livelihoods; Forestry Paper No. 175; Food and Agriculture Organization of the United Nations: Rome, Italy, 2015.

10. Convention on Biological Diversity (CBD). Strategic Plan for Biodiversity 2011-2020. 2011. Available online: https://www.cbd.int/sp/targets/default.shtml (accessed on 3 December 2020).

11. IUCN and WRI. A Guide to the Restoration Opportunities Assessment Methodology (ROAM): Assessing Forest Landscape Restoration Opportunities at the National or Sub-National Level; IUCN: Gland, Switzerland, 2014.

12. United Nations (UN). Social Development Goals, Goal 15: Sustainably Manage Forests, Combat Desertification, Halt and Reverse Land Degradation, Halt Biodiversity Loss. 2015. Available online: https://www.un.org/sus tainabledevelopment/sustainable-development-goals/ (accessed on 3 December 2020).

13. Ministère de l'Environnement, de l'Economie Verteet du Changement Climatique du Burkina Faso (MEEVCC). Rapport Final, Programme de Définition des Cibles de la Neutralité en Matière de Dégradation des Terres (PDC/NDT), Burkina Faso; MEEVCC: Ouagadougou, Burkina Faso, 2018.

14. Food Agriculture Organization. Global Forest Resources Assessment; UN Food Agriculture Organization: Rome, Italy, 2015.

15. Ouedraogo, I.; Mbow, C.; Balinga, M.; Neufeldt, H. Transitions in Land Use Architecture under Multiple Human Driving Forces in a Semi-Arid Zone. Land 2015, 4, 560-577. [CrossRef]

16. Murcia, C.; Guariguata, M.R. La Restauración Ecológica en Colombia: Tendencias, Necesidades y Oportunidades; Centre for International Forestry Research: Bogor, Indonesia, 2014; ISBN 978-602-1504-35-2.

17. Ministère de l'Environnement, de l'Economie Verte et du Changement Climatique du Burkina Faso (MEEVCC). Plan d'Action de Reforestation du Burkina Faso 2018-2022; MEEVCC: Ouagadougou, Burkina Faso, 2017.

18. Gammoh, I.A.; Oweis, T.Y. Contour Laser Guiding for the Mechanized "Vallerani" Micro-catchment Water Harvesting Systems. J. Environ. Sci. Eng. 2011, 5, 1309-1316.

19. Zida, M. Reshaping the Terrain: Forest and Landscape Restoration in Burkina Faso. Global LANDSCAPE Forum Factsheet. 2018. Available online: https://www.cifor.org/publications/pdf_files/factsheet/6984-GLF_ Factsheet.pdf (accessed on 11 December 2020).

20. Girard, H. Wégoubri, the sahelian bocage: An integrate approach for environment preservation and social development in sahelian agriculture (Burkina Faso). Field Actions Sci. Rep. 2009, 2, 33-39. [CrossRef]

21. Belem, B.; Kaguembega-Mueller, F.; Bellefontaine, R.; Sorg, J.R.; Bloesch, U.; Graf, E. Assisted natural regeneration with fencing central and northern zones of Burkina Faso. Tropicultura 2017, 35, 73-86. [CrossRef]

22. Gutierrez, V.; Keijzer, M.-N. Funding forest landscape restoration using a business-centred approach: An NGO's perspective. Unasylva 2015, 245, 99-106.

23. Schuyt, K. Opportunities for long term financing of forest restoration in landscapes. In Forest Restoration in Landscapes-Beyond Planting Trees; Mansourian, S., Vallauri, D., Dudley, N., Eds.; Springer: New York, NY, USA, 2005; pp. 161-176.

24. Zizka, A.; Thiombiano, A.; Dressler, S.; Nacoulma, B.M.; Ouédraogo, A.; Ouédraogo, I.; Ouédraogo, O.; Zizka, G.; Hahn, K.; Schmidt, M. Traditional plant use in Burkina Faso (West Africa): A national-scale analysis with focus on traditional medicine. J. Ethnobiol. Ethnomed. 2015, 11, 9. [CrossRef] [PubMed] 
25. Ouedraogo, B. Household energy preferences for cooking in urban Ouagadougou, Burkina Faso. Energy Policy 2006, 34, 3787-3795. [CrossRef]

26. Shackleton, C.M.; Shackleton, S.E.; Buiten, E.; Bird, N. The importance of dry woodlands and forests in rural livelihoods and poverty alleviation in South Africa. Forest Policy Econ. 2007, 9, 558-577. [CrossRef]

27. Gadzama, N.M. Attenuation of the effects of desertification through sustainable development of Great Green Wall in the Sahel of Africa. World J. Sci. Technol. Sustain. Dev. 2017, 14, 279-289. [CrossRef]

28. Goffner, D.; Sinare, H.; Gordon, L.J. The Great Green Wall for the Sahara and the Sahel Initiative as an opportunity to enhance resilience in Sahelian landscapes and livelihoods. Reg. Environ. Chang. 2019, 19, 1417-1428. [CrossRef]

29. Reenberg, A. Insistent Dryland Narratives: Portraits of Knowledge about Human-Environmental Interactions in Sahelian Environment Policy Documents. West Afr. J. Appl. Ecol. 2012, 20, 97-111.

30. O'Connor, D.; James, F. Increasing the Effectiveness of the "Great Green Wall" as an Adaptation to the Effects of Climate Change and Desertification in the Sahel. Sustainability 2014, 6, 7142-7154. [CrossRef]

31. Coulibaly-Lingani, P.; Savadogo, P.; Tigabu, M.; Oden, P.-C. Factors influencing people's participation in the forest management program in Burkina Faso, West Africa. Forest Policy Econ. 2011, 13, 292-302. [CrossRef]

32. Ndangalasi, H.J.; Bitariho, R.; Dovie, D.B.K. Harvesting of non-timber forest products and implications for conservation in two montane forests of East Africa. Biol. Conserv. 2007, 134, 242-250. [CrossRef]

33. Bougma, L.A.; Sawadogo, N.; Ouedraogo, M.H.; Ouedraogo, M.; Balma, D.; Sawadogo, M. Overview of the Burkina Faso seed system: Case of the formal seed system. Int. J. Agric. Policy Res. 2018, 6, 169-175.

34. Sacande, M.; Berrahmouni, N.; Hargreaves, S. Community participation at the heart of Africa's Great Green Wall restoration model. Unasylva 2015, 66, 44-51.

35. Sacande, M.; Berrahmouni, N. Community participation and ecological criteria for selecting species and restoring natural capital with native species in the Sahel: Restoring natural capital in the Sahel. Restor. Ecol. 2016, 24, 479-488. [CrossRef]

36. Gómez, J.M.; Hódar, J.A.; Baraza, E.; Gómez-Aparicio, L.; Castro, J.; Zamora, R. Applying Plant Facilitation To Forest Restoration: A Meta-Analysis of the Use of Shrubs As Nurse Plants. Ecol. Appl. 2004, 14, 1128-1138. [CrossRef]

37. Gómez-Aparicio, L.; Gómez, J.M.; Zamora, R.; Boettinger, J.L. Canopy vs. soil effects of shrubs facilitating tree seedlings in Mediterranean montane ecosystems. J. Veg. Sci. 2005, 16, 191-198. [CrossRef]

38. Bogie, N.A.; Bayala, R.; Diedhiou, I.; Conklin, M.H.; Fogel, M.L.; Dick, R.P.; Ghezzehei, T.A. Hydraulic Redistribution by Native Sahelian Shrubs: Bioirrigation to Resist In-Season Drought. Front. Environ. Sci. 2018, 6. [CrossRef]

39. Dossa, E.L.; Khouma, M.; Diedhiou, I.; Sene, M.; Kizito, F.; Badiane, A.N.; Samba, S.A.N.; Dick, R.P. Carbon, nitrogen and phosphorus mineralization potential of semiarid Sahelian soils amended with native shrub residues. Geoderma 2009, 148, 251-260. [CrossRef]

40. Hernandez, R.R.; Debenport, S.J.; Leewis, M.C.C.E.; Ndoye, F.; Nkenmogne, K.I.E.; Soumare, A.; Thuita, M.; Gueye, M.; Miambi, E.; Chapuis-Lardy, L.; et al. The native shrub, Piliostigma reticulatum, as an ecological "resource island" for mango trees in the Sahel. Agric. Ecosyst. Environ. 2015, 204, 51-61. [CrossRef]

41. Baynes, J.; Gregorio, N. Nursery Training for Smallholders: An Evaluation of Two Extension Programs in the Philippines. Small-Scale For. 2008, 7, 387-401. [CrossRef]

42. Farmers' Planting Practices in Burkina Faso: A Survey Carried Out by the Project "Improved Seed Supply for Agroforestry in African Countries. Available online: https://www.semanticscholar.org/paper/Farmers\% 27-planting-practices-in-Burkina-Faso-A-out-R\%C3\%A6bild-Bassirou/7ab1d41b668614a105db32263e272 e6dd922f1e2 (accessed on 11 December 2020).

43. Belem, B.; Nacoulma, B.M.I.; Gbangou, R.; Kambou, S.; Hansen, H.H.; Gausset, Q.; Lund, S.; Raebild, A.; Lompo, D.; Ouedraogo, M.; et al. Use of Non Wood Forest Products by local people bordering the "Parc National Kaboré Tambi", Burkina Faso. J. Transdiscipl. Environ. Stud. 2007, 6, 1-21.

44. Lykke, A.M.; Kristensen, M.K.; Ganaba, S. Valuation of local use and dynamics of 56 woody species in the Sahel. Biodivers. Conserv. 2004, 13, 1961-1990. [CrossRef]

45. Suárez, A.; Williams-Linera, G.; Trejo, C.; Valdez-Hernández, J.I.; Cetina-Alcalá, V.M.; Vibrans, H. Local knowledge helps select species for forest restoration in a tropical dry forest of central Veracruz, Mexico. Agrofor. Syst. 2012, 85, 35-55. [CrossRef] 
46. Bayen, P.; Lykke, A.M.; Thiombiano, A. Success of three soil restoration techniques on seedling survival and growth of three plant species in the Sahel of Burkina Faso (West Africa). J. For. Res. 2016, 27, 313-320. [CrossRef]

47. Crouzeilles, R.; Ferreira, M.S.; Chazdon, R.L.; Lindenmayer, D.B.; Sansevero, J.B.B.; Monteiro, L.; Iribarrem, A.; Latawiec, A.E.; Strassburg, B.B.N. Ecological restoration success is higher for natural regeneration than for active restoration in tropical forests. Sci. Adv. 2017, 3, e1701345. [CrossRef]

48. Haglund, E.; Ndjeunga, J.; Snook, L.; Pasternak, D. Dry land tree management for improved household livelihoods: Farmer managed natural regeneration in Niger. J. Environ. Manag. 2011, 92, 1696-1705. [CrossRef] [PubMed]

49. Sendzimir, J.; Reij, C.P.; Magnuszewski, P. Rebuilding Resilience in the Sahel: Regreening in the Maradi and Zinder Regions of Niger. Ecol. Soc. 2011, 16, art1. [CrossRef]

50. Weston, P.; Hong, R.; Kaboré, C.; Kull, C.A. Farmer-Managed Natural Regeneration Enhances Rural Livelihoods in Dryland West Africa. Environ. Manag. 2015, 55, 1402-1417. [CrossRef] [PubMed]

51. Rinaudo, T.; Muller, A.; Morris, M. Farmer Managed Natural Regeneration (FMNR) Manual; World Vision Australia: Melbourne, Australia, 2019.

52. Descheemaeker, K.; Muys, B.; Nyssen, J.; Poesen, J.; Raes, D.; Haile, M.; Deckers, J. Litter production and organic matter accumulation in exclosures of the Tigray highlands, Ethiopia. For. Ecol. Manag. 2006, 233, $21-35$. [CrossRef]

53. Gebremedihin, K.; Birhane, E.; Tadesse, T.; Gbrewahid, H. Restoration of degraded drylands through exclosures enhancing woody species diversity and soil nutrients in the highlands of Tigray, Northern Ethiopia. Nat. Conserv. Res. 2018, 3. [CrossRef]

54. Valette, M.; Traoré, D.; Kaguembèga-Müller, F.; Traoré, A.T.; Vinceti, B. Initiative to restore forest landscapes through household-managed fenced plots in Burkina Faso. Nat. Faune 2018, 66, 65-70.

55. Gebregziabher, D.; Soltani, A. Exclosures in people's minds: Perceptions and attitudes in the Tigray region, Ethiopia. For. Policy Econ. 2019, 101, 1-14. [CrossRef]

56. Kassa, H.; Birhane, E.; Bekele, M.; Lemenih, M.; Tadesse, W.; Cronkleton, P.; Putzel, L.; Baral, H. Shared strengths and limitations of participatory forest management and area exclosure: Two major state led landscape rehabilitation mechanisms in Ethiopia. Int. For. Rev. 2017, 19, 51-61. [CrossRef]

57. Ky-Dembele, C.; Tigabu, M.; Bayala, J.; Ouédraogo, S.J.; Odén, P.C. The relative importance of different regeneration mechanisms in a selectively cut savanna-woodland in Burkina Faso, West Africa. For. Ecol. Manag. 2007, 243, 28-38. [CrossRef]

58. Maisharou, A.; Chirwa, P.W.; Larwanou, M.; Babalola, F.; Ofoegbu, C. Sustainable land management practices in the Sahel: Review of practices, techniques and technologies for land restoration and strategy for up-scaling. Int. For. Rev. 2015, 17, 1-19. [CrossRef]

59. Chazdon, R.L.; Guariguata, M.R. Natural regeneration as a tool for large-scale forest restoration in the tropics: Prospects and challenges. Biotropica 2016, 48, 716-730. [CrossRef]

60. Hänke, H.; Börjeson, L.; Hylander, K.; Enfors-Kautsky, E. Drought tolerant species dominate as rainfall and tree cover returns in the West African Sahel. Land Use Policy 2016, 59, 111-120. [CrossRef]

61. Chirwa, P.W.; Mahamane, L. Overview of restoration and management practices in the degraded landscapes of the Sahelian and dryland forests and woodlands of East and southern Africa. South. For. J. For. Sci. 2017, 79, 87-94. [CrossRef]

62. Sawadogo, H. Using soil and water conservation techniques to rehabilitate degraded lands in northwestern Burkina Faso. Int. J. Agric. Sustain. 2011, 9, 120-128. [CrossRef]

63. Valette, M.; Vinceti, B.; Traoré, D.; Traoré, A.T.; Yago-Ouattara, E.L.; Kaguembèga-Müller, F. How Diverse is Tree Planting in the Central Plateau of Burkina Faso? Comparing Small-Scale Restoration with Other Planting Initiatives. Forests 2019, 10, 227. [CrossRef]

64. Roshetko, J.M.; Idris, N.; Purnomosidhi, P.; Zulfadhli, T.; Tarigan, J. Farmer extension approach to rehabilitate smallholder fruit agroforestery systems: The “Nurseries Of Excellence (NOEL)" program in Aceh, Indonesia. Acta Hortic. 2013, 649-656. [CrossRef]

65. Takoutsing, B.; Tchoundjeu, Z.; Degrande, A.; Asaah, E.; Gyau, A.; Nkeumoe, F.; Tsobeng, A. Assessing the Quality of Seedlings in Small-scale Nurseries in the Highlands of Cameroon: The Use of Growth Characteristics and Quality Thresholds as Indicators. Small-Scale For. 2014, 13, 65-77. [CrossRef] 
66. Catacutan, D.; Bertomeu, M.; Arbes, L.; Duque, C.; Butra, N. Fluctuating Fortunes of a Collective Enterprise: The Case of the Agroforestry Tree Seeds Association of Lantapan (ATSAL) in the Philippines. Small-Scale For. 2008, 7, 353-368. [CrossRef]

67. Tchoundjeu, Z.; Degrande, A.; Leakey, R.R.B.; Nimino, G.; Kemajou, E.; Asaah, E.; Facheux, C.; Mbile, P.; Mbosso, C.; Sado, T.; et al. Impacts of Participatory Tree Domestication on Farmer Livelihoods in West and Central Africa. For. Trees Livelihoods 2010, 19, 217-234. [CrossRef]

68. Jacobs, D.F.; Salifu, K.F.; Seifert, J.R. Relative contribution of initial root and shoot morphology in predicting field performance of hardwood seedlings. New For. 2005, 30, 235-251. [CrossRef]

69. Wightman, K.E.; Shear, T.; Haggar, J. Nursery and field establishment techniques to improve seedling growth of three Costa Rican hardwoods. New For. 2001, 22, 75-96. [CrossRef]

70. Etongo, D.; Djenontin, I.; Kanninen, M.; Fobissie, K. Smallholders' Tree Planting Activity in the Ziro Province, Southern Burkina Faso: Impacts on Livelihood and Policy Implications. Forests 2015, 6, 2655-2677. [CrossRef]

71. Galabuzi, C.; Eilu, G.; Mulugo, L.; Kakudidi, E.; Tabuti, J.R.S.; Sibelet, N. Strategies for empowering the local people to participate in forest restoration. Agrofor. Syst. 2014, 88, 719-734. [CrossRef]

72. Agarwal, B. Participatory Exclusions, Community Forestry, and Gender: An Analysis for South Asia and a Conceptual Framework. World Dev. 2001, 29, 1623-1648. [CrossRef]

73. Westholm, L.; Arora-Jonsson, S. Defining Solutions, Finding Problems: Deforestation, Gender, and REDD+ in Burkina Faso. Conserv. Soc. 2015, 13, 189-199. [CrossRef]

74. Herrmann, S.M.; Tappan, G.G. Vegetation impoverishment despite greening: A case study from central Senegal. J. Arid Environ. 2013, 90, 55-66. [CrossRef]

75. Le, H.D.; Smith, C.; Herbohn, J.; Harrison, S. More than just trees: Assessing reforestation success in tropical developing countries. J. Rural Stud. 2012, 28, 5-19. [CrossRef]

76. Jalonen, R.; Valette, M.; Boshier, D.; Duminil, J.; Thomas, E. Forest and landscape restoration severely constrained by a lack of attention to the quantity and quality of tree seed: Insights from a global survey. Conserv. Lett. 2018, 11. [CrossRef]

77. Mclain, R.; Lawry, S.; Guariguata, M.R.; Reed, J. Toward a tenure-responsive approach to forest landscape restoration: A proposed tenure diagnostic for assessing restoration opportunities. Land Use Policy 2018, 1-12. [CrossRef]

78. Viani, R.A.G.; Holl, K.D.; Padovezi, A.; Strassburg, B.B.N.; Farah, F.T.; Garcia, L.C.; Chaves, R.B.; Rodrigues, R.R.; Brancalion, P.H.S. Protocol for Monitoring Tropical Forest Restoration: Perspectives From the Atlantic Forest Restoration Pact in Brazil. Trop. Conserv. Sci. 2017, 10. [CrossRef]

Publisher's Note: MDPI stays neutral with regard to jurisdictional claims in published maps and institutional affiliations.

(C) 2020 by the authors. Licensee MDPI, Basel, Switzerland. This article is an open access article distributed under the terms and conditions of the Creative Commons Attribution (CC BY) license (http://creativecommons.org/licenses/by/4.0/). 